\title{
MORPHOFUNCTIONAL CHANGES OF THE PELVIC ORGANS UNDER CONDITIONS OF STRESS URINARY INCONTINENCE AND EXPERIMENTAL VAGINAL PROLAPSE
}

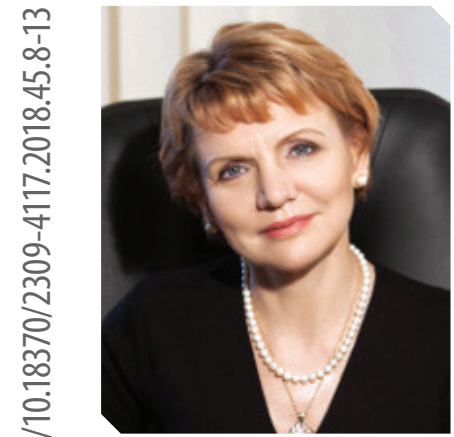

T.F. TATARCHUK

MD, professor, corresponding member of the NAMS of Ukraine, deputy director for research work, head of the Endocrine Gynecology Department, SI “0.M. Lukyanova Institute of Pediatrics, Obstetrics and Gynecology of the NAMS of Ukraine" ORCID: 0000-0002-5498-4143

\subsection{YEFIMENKO}

$\mathrm{PhD}$, senior researcher at the Endocrine Gynecology Department, SI “0.M. Lukyanova Institute of

Pediatrics, Obstetrics and Gynecology of the NAMS of Ukraine" ORCID: 0000-0003-1228-0911

\section{V.S. SHKOLNIKOV}

MD, professor, Human Anatomy Department, N.I. Pirogov Vinnitsa

National Medical University

ORCID: 0000-0001-8233-1863

\section{Contacts:}

Tetiana F. Tatarchuk

SI "O.M. Lukyanova IPOG of the NAMS of Ukraine"

Endocrine Gynecology Department 04050, Kyiv, Maiborody str., 8

tel.: +38 (044) 4838087

Email: ipag.gyn@femina-health.org

\section{INTRODUCTION}

At the present time, difficulties in solving the problem of etiology and pathogenesis of the genital prolapse persist. Most authors consider a multidimensionality to be the cause, at the same time referencing different groups of causes as the most important. Most researchers consider the polyetiologic nature of the disease [1].

A significant number of genital prolapse cases in women is caused by systemic changes in connective tissue, trauma of the connective apparatus of the genital organs and pelvic floor fasciae, microcirculatory and trophic disorders (especially in elderly and hyposthenia persons), and the deficiency of estrogen. This is so-called "fatigue-driven" prolapse [2, 3].

According to Troiano L. et al. [4], the main role in occurrence of the prolapse belongs to changes in fixing ligaments - cardinal and sacro-uterine ones. Atrophy and destruction of these ligaments tissue may cause descent and prolapse of genital organs.

Pelvic floor circulatory tissue disorders are mostly observed with underlying genital prolapse. Local microcirculatory changes at initial severity of genital prolapse were characterized by a decrease in a peripheral resistance of blood vessels with underlying decrease of the total vascular tone, overflow of the venular bed, and reflected the general parameters of the microcirculatory blood flow, while disturbance of local, adaptive mechanisms of the entire microcirculation system with involvement of arterioles was characteristic for the expressed forms of the disease [3].

In more than $30 \%$ of cases of internal organs' descensus and prolapse, histologic methods revealed both dystrophic changes of vulva walls and inflammatory infiltrates in the the mucous tunic layer [5]. Therefore, the tone, strength and elasticity of the post-menopause pelvic floor progressively decreased, and the number of patients suffering from genitals prolapse increased in elder age groups [6].

Estrogen deficiency is believed to be the most important factor that influences metabolic processes in the connective tissue and chemical composition of the intercellular media. This was manifested by deceleration of the processes of collagen synthesis and decreased elasticity of the connective tissue $[7,8]$.

Estrogen synthesis deficiency, leading to impairment of circulation and microcirculation in the pelvic floor tissues, as well as to reduction of elasticity thereof, contributed to a prolapse of genital organs. Hereditarily deterministic defect in molecular structure of the collagen resulting in a decrease of the strength of fixing apparatus and fasciae of the pelvic floor is considered a factor of risk for development of the genital prolapse [9].

In this regard, a theory of systemic dysplasia of connective tissue has come to the fore as the leading cause of prolapses. In this case, childbearing and injuries are considered only provocative factors [10].

Dysplasia of the connective tissue is a congenital anomaly preconditioned by disturbance in the structure of fibrous components of predominantly collagen or basic substance, and is manifested by a decrease in its strength [11]. A reduction of the content of certain types of collagen or disturbance of relation between them, which leads to a decrease in the strength of connective tissue of many organs and systems, is considered a morphological background of the disease.

Clarifying the role of collagens in the etiology of urinary incontinence and genital prolapse may be a clue for solving important pathogenetic issues [12].

The genius prolapse is usually accompanied by urinary incontinence. A displacement of organs in this case affects the condition of predominantly bladder and urethra, causing overactivity thereof. The motility of these organs aggravates, thus causing a hypermotivity $[13,14]$.

Reflexes of the lower urinary tract that are susceptible to ascending sensory stimulation at different levels of the central nervous system are sensitive to stress factors [15].

Growing number of patients with genital prolapse and combining this condition with stress urinary incontinence (SUI) requires further research. Inadequate efficacy of many existing regimens for treatment of genital prolapse, accompanied by urinary incontinence, encourages researchers to find new approaches. Using models and development of experimental therapy regimens based on them will contribute to solving the problem.

\section{STUDY MATERIALS AND METHODS}

During the study, we examined the condition of the bladder and vulva tissues in 30 white rats. Animals were divided into three groups. The first control group consisted of intact animals. The SUI model was replicated in animals of the second experimental group [16]; SUI model in white fe- 
male rats of the third group was supplemented by modelled vaginal prolapse (VP). For these purposes, after preparation of a surgical field in the upper part of animal's thigh, we performed an incision, expanded the edges of the wound up to exposure of the sciatic nerve, then ligated it with a thread in the proximal section before branching of the pudendal nerve, and completed the surgery by layer-by-layer wound suturing, followed by application of gentamicin ointment to prevent its infection. Using this model, we managed to obtain a steady and stable decrease in the pressure of the first urine drop.

After replication of the SUI model, we caused a breach of the vaginal vault fixation to the sacro-uterine ligament, thus reaching the prolapse.

For surgical interventions in rats, we used intraperitoneal anesthesia consisted of $5 \%$ sodium thiopental solution 0.2 $\mathrm{ml}$ and $1 \%$ Propofol solution $0.4 \mathrm{ml}$.

The surgical interventions were performed in compliance with the requirements of the Law of Ukraine No. 1759-IV dated December 15, 2009 "On Protection of Animals from Cruel Treatment" and standards of the "Guide for the Core and Use of Laboratory Animals (National Academy Press, Revised, 1996), and American Heart Association's Guidelines for the use of animal in research [17].

Post-euthanasia, we removed the bladder, urethra and vagina from the animals and fixed them a $10 \%$ solution of buffered formalin. After fixation, the organs were sealed in paraffin. $7 \mu \mathrm{m}$ thick paraffin slices were made using Leica RM2125 RT rotor microtome. Deparaffined slices were stained with hematoxylin and eosin, and van Gison picro fuchsin. MacManus Periodic Acid-Schiff (PAS) reaction with amylase control was used to analyze tissue changes. Images of histological preparations were made with the help of a digital camera of Olympus BX 41 optical microscope.

Morphometric studies, which were determining the density of vessels of the microcirculatory bed of the proper vulva plate, were carried out using Olympus BX 41 light-optical microscope (magnification: eyepiece $-\mathrm{x} 10$, lens $-\mathrm{x} 10$ ) using the Paradise Image Analysis program developed by Eva research and production company (Ukraine). The statistical processing of the results of the study was performed using Student's t-test.

\section{STUDY RESULTS}

The histologic preparations of the bladder of females rats from the control group were covered from inside with a transitional epithelium consisting of 6-10 cell rows, the proper plate was flaky, had a thin compacted layer under the epithelial plate. The mucous membrane formed mostly even folds. Submucosal basis was poorly developed and absent in the triangle area. Bundles of smooth muscle cells were located in the muscle layer, which made up three unclearly separated layers with thin layers of loose connective tissue between them. Bladder myocytes in the triangle zone formed a circular layer; the submucosal layer was absent (Fig.1). The bulk surface of the bladder was covered from the outside with a thin serous membrane.

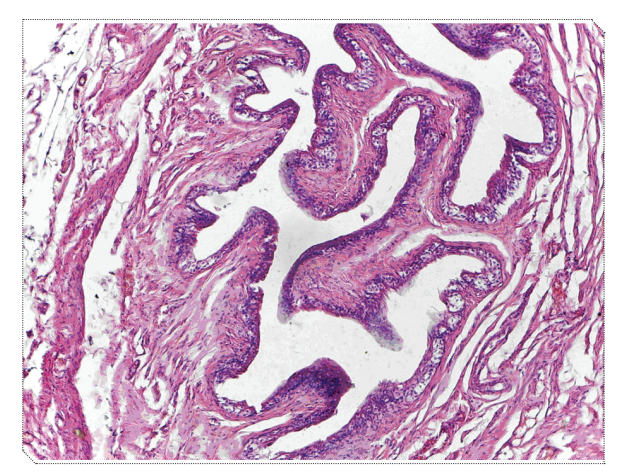

Figure 1. Bladder (closer to sphincter)

Hematoxylin and eosin staining. Magnification 100

The urethral wall consisted of a mucosal membrane that was very similar to the bladder membrane, yet with a less developed proper plate, a thin submucosal membrane, well developed muscle layer with circularly located bundles of smooth myocytes. Small glands were visible in the upper part of the urethra.

The mucousal membrane of the vulva was covered with 7-9 rows of epithelial cells, sometimes signs of keratinization were observed. Surface epithelial cells contained glycogen grains. The proper plate was formed by a loose connective tissue, which was somewhat denser under the epithelial plate due to a compact location of thin collagen fiber bundles. Closer to the muscular membrane, the proper plate appeared to be looser (Fig. 2).
The muscular membrane was rather thin, made up mainly of longitudinal bundles of smooth myocytes. The basis of the adventitious tunic consisted of a loose connective tissue with thicker bundles of collagen fibers, positioned slightly denser. The density of blood vessels was smaller than that in the proper plate; the vessels themselves were mainly of a larger diameter.

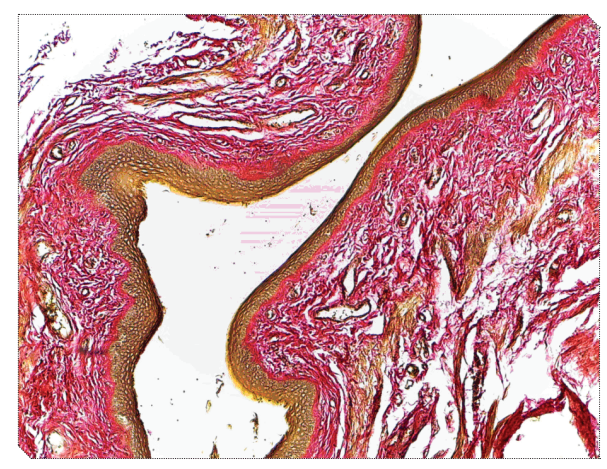

Figure 2. Vulva of female rat of the control group Van Gieson picro-fuchsin staining. Magnification 100

On Day 14 after replication of the SUI model, a focal exfoliation of superficial cells of the epithelial plate was observed in the bladder, however in other areas, the epithelial plate was almost unchanged, or even thickened due to excessive contraction of the smooth muscle cells. Moderately tonically contracted muscular membrane did not have any expressed departures from norm. The serous membrane was also preserved without departures.

The urethra was somewhat dilated with increased exfoliation of epithelial cells observed on the tops of folds. The muscular membrane was moderately atonic, without pronounced pathological changes.

The epithelial plate of the vagina was hypertrophied, the blood vessels of the proper plate were dilated, the veins and venules full-blooded. The muscle layer did not feature any departures from the norm.

Within 30 days after replication of the SUI model, the epithelial plate of the mucous membrane of the bladder was significantly thinned, some sites underwent significant desquamation, blood vessels dilated, full-blooded were mainly capillaries and venules. The musculoskeletal system contracted unevenly, the areas of significant contraction were observed, as evidenced by deep folds in the areas of excessive contraction, formed by the 
mucosal and submucosal membranes, and by the abnormally high intensity of smooth muscle cells' staining. The serous membrane was without significant changes.

On Day 30 after replication of the SUI model, the urethra was significantly dilated and had isolated folds. The epithelial plate was thinned and partly exfoliated, the muscular membrane was atonic. The blood vessels of all membranes were moderately dilated.

30 days after replication of the SUI model, the vagina was characterized by thinned epithelial plate, the epithelial-dermal border was smoothed, and the proper mucosal plate had signs of edema, compacted due to increased density of collagen fibers (Fig. 3). The muscle layer was atonic with increased number of collagen fibers that formed a mesh around the bundles of smooth muscle cells.

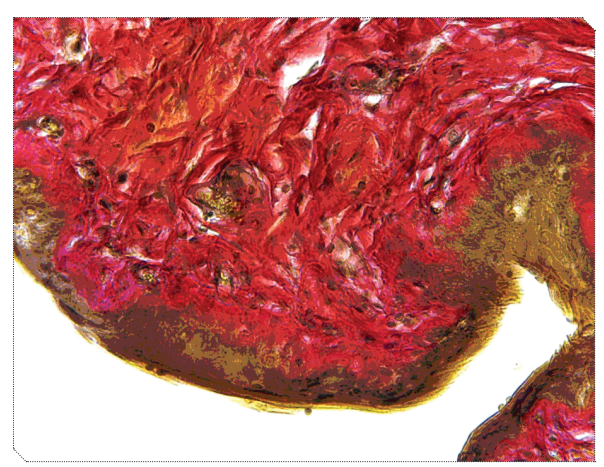

Figure 3. Vulva of female rat 30 days after replication of the stress model

Van Gieson picro-fuchsin staining. Magnification 400

14 day after replication of combined SUI and VP model, epithelial plate thinning and mild desquamation in small areas were observed in the urinary bladder. The mucous membrane formed deep, branched folds, which almost completely filled the lumen of the organ (Fig. 4). Blood vessels of the proper plate of mucous membrane and submucosal basis were full-blooded and dilated. Myocytes of the muscle layer were partially contracted, acidophilic-stained. The serous membrane did not have any departures from the norm.

On Day 14 after the replication of the complex SUI and VP model, the urethral lumen was flattened. The epithelial plate underwent desquamation and atrophic changes. In the proper plate

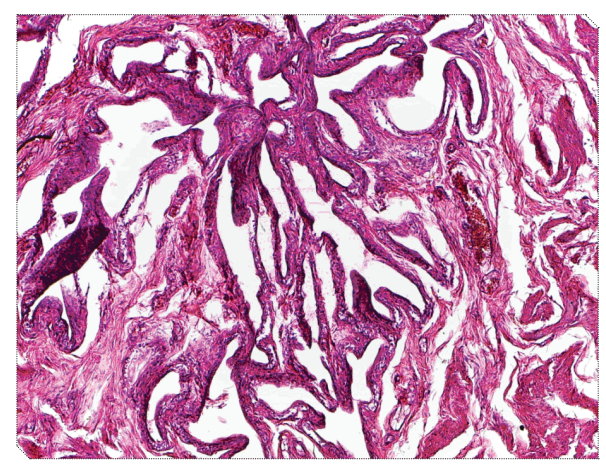

Figure 4. Bladder of white female rat 14 days after replication of SUI and VP model Hematoxylin and eosin staining. Magnification 100

of the mucous membrane, and especially in the submucosal region, sharply dilated blood vessels, mainly veins and venules, were observed. In the muscle membrane, an increase in the number of collagen fibers and a decrease in the density of smooth myocytes bundles were observed.

14 days after replication of the model, the epithelial plate of the vagina underwent hypertrophy and thickened significantly. At the same time, dystrophic changes were observed in it, mainly in the intermediate and superficial layers. The cells of the surficial layer completely lost glycogen grains. The proper plate of the mucous membrane hardened; not only the number of collagen fiber bundles increased, but also the diameter thereof (Fig. 5); the number of vessels of the hemomycocirculatory bed went down. In the muscular membrane, more numerous and thick collagen fibers were positioned between the bundles of smooth muscle cells.

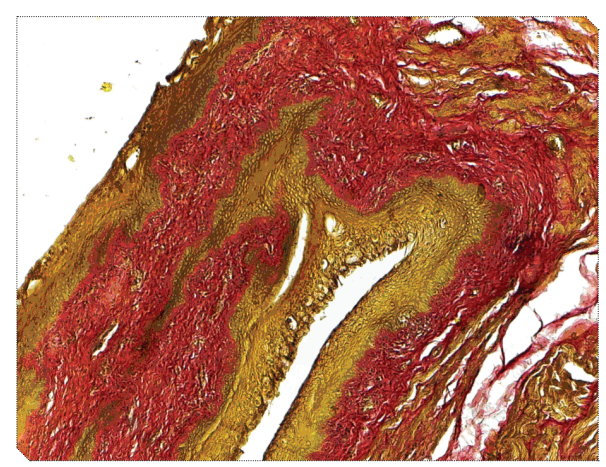

Figure 5. Vulva of white female rat 14 days after replication of SUI and VP model Van Gieson picro-fuchsin staining. Magnification 100

Within 30 days after replication of SUI and VP model, the epithelial plate of the mucosal membrane of the bladder significantly thinned up to 2-4 cell layers; intensified desquamation was observed in some areas, which led to surface exposure. The proper plate indurated throughout the depth; the number of thick collagen fiber bundles in it and in the submucosa grew. The density of vessels of the microcirculatory bed decreased. Both the volume of collagen and the diameter of bundles and the width of connective tissue layers increased in the muscular membrane between the bundles of smooth muscle cells. The foci of mesothelium detachment were noted in the serous membrane.

In the urethra, an accelerated desquamation of superficial cells and detached cells in the lumen was observed. The proper plate swelled, the tincture properties of collagen fibers changed, which suggested not only their swelling, but also the destruction thereof. The muscular membrane was thinning, turning atonic.

In the vagina, the pronounced atrophic changes were observed mainly in the mucosal coat. The epithelial plate was thickening, undergoing destruction at some sites (Fig. 6); detritus masses were observed in the lumen of the vulva, glycogen grains in epithelial cells were not found. The proper plate of the mucosal membrane was turning sclerous because of edema and thickening of the collagen fibers. The number of blood vessels of the microcirculatory bed continued to decrease compared with the previous term. The muscular membrane was atonic, the cytoplasm of myocytes changed its tincture properties, turned slightly acidophilic, slightly basophilic in some areas, suggesting a disturbance of metabolic processes.

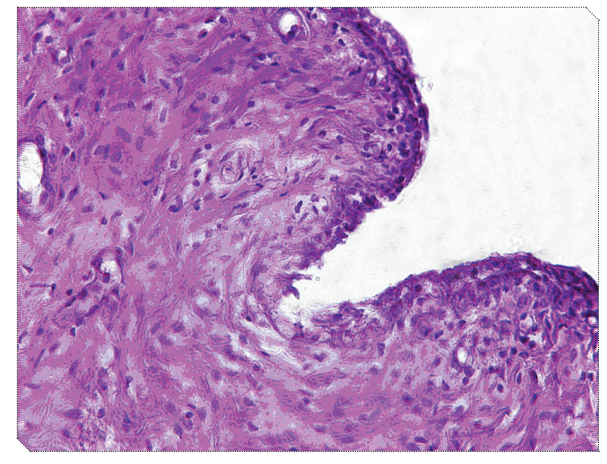

Figure 6. Vulva of female rat 30 days after replication of SUI and VP model

Expressed desquamation of epithelial cells. PAS-reaction. Magnification 40 


\section{RESULTS DISCUSSION}

After replication of SUI and combined SUI + VP models, all study organs underwent changes well after 14 days.

After replication of SUI model in the bladder, desquamation of superficial epithelial cells increased, however, at the same time, compensatory processes caused moderate hypertrophy in the intermediate layer; the contraction of smooth muscle cells of the muscular layer somewhat increased the tone.

In the urethra, moderately pronounced functional changes, predominantly in smooth muscle elements, were prevailing. In the vagina, the most pronounced changes were noted in the mucosal membrane, accompanied with signs of hypertrophy in the epithelial plate and the signs of moderate edema with full-blooded vessels in the proper plate.

30 days after replication of SUI model, atrophic changes in the mucous membranes manifested predominantly in bladder and vulva. The proper plates of mucous membranes of all study organs turned sclerous mainly due to edema, however the density of collagen fibers increased somewhat, i.e. the collagen genesis intensified. The myocytes of the bladder muscle layer were tonically contracted, while signs of atony were observed in the muscle layer of both urethra and vulva.

Using the combined SUI + VP model resulted in intensification of desquamation of superficial cells of the epithelial plate in the mucosal layer of the bladder in 14 days. The tone of the blood vessels in all membranes decreased; they mainly dilated, especially the veins. In the muscular membrane, the tone of myocytes increased, which manifested by intense staining of the cytoplasm, the presence of spiral form cores, as well as deep, numerous, branched folds of the mucosal membrane.

In the urethra, an increased exfoliation of epithelial plate cells was also obvious, accompanied with manifestations of edema in the proper plate. Edema extended to the muscle layer, causing swelling of the connective tissue layers. In addition, their moderate growth was observed. However, myocytes were tonically contracted, with no pronounced signs of dystrophic changes.

In the vagina, the epithelial plate was hypertrophied and had manifestations of dystrophy. The proper plate was sclerous due to increased collagen, with decreased tone of myocytes in the muscular membrane compared to the control group.

30 days after replication of the combined model, there were more pronounced disorders of the morphofunctional state of the epithelial and connective tissues of the subject organs. In the bladder, the epithelial plate was significantly thinned, and the increased desquamation led to focal exposure of the proper plate. The sclerotic changes in the proper plate were more pronounced than in the previous term. The number of vessels in the hemomicrocirculatory bed continued to decrease. The muscular membrane showed the growth and consolidation of the connective tissue layers, as smooth muscle cells retained a tone. The integrity of the mesothelial plate of the serous membrane was broken. In the urethra, the desquamation of the epithelial cells increased, and edema of the proper plate was observed. The urethra muscle membrane, unlike the bladder coat, turned atonic, and signs of dystrophic changes in myocytes became more pronounced. The vulva coat underwent the atrophic changes manifested by sedentary destruction of the epithelial plate, edema of the connective tissue, dystrophy of smooth muscle cells, and a significant weakening of the tone.

Therefore, in animals of the second groups with SUI model, mostly functional changes were observed. Vulva tissues under this model appeared to be sensitive to disturbances, especially the tissues of the mucous and muscle membranes, where morphological changes were revealed in addition to functional ones.

After replication of SUI and VP model, there were destructive processes in the mucous membranes of the bladder, urethra and vulva, the volume of connective tissue in the muscular membranes increased both around and between the muscle bundles, accompanied by thickening collagen fibers and changes associated with manifestation of destruction in the later term (30 days).

The morphometric studies revealed that the density of capillaries decreased (Table) in the proper plate of the vulva mucosa of animals in both second and third groups - by $12.35 \%$ and $34.24 \%$ in animals of the second group with SUI model and in animals of the third group with a combined model, accordingly. The diameter of arteriole and vein lumen increased due to atony of vascular wall, and the vessels of venous type demonstrated a more pronounced atony. The walls of arterioles in animals of the second group did not undergo the expressed changes, but in animals of the third group, they were thickening due to sclerotic

The displacement of vulva resulted in compression of its tissues with the edema, which was accompanied by growing and consolidation of collagen fibers, muscle atrophy, loss of density of microcirculatory bed vessels, especially capillaries.

The combination of these processes led to a disturbance of architectonics and a ratio between muscle and connective tissue in the membranes of the study organs. Dystrophy and swelling were associated with these processes. The aggravated vulva atony suggested a decrease in a number of elastic fibers around the vessels and muscle bundles.

\section{CONCLUSIONS}

1. Replication of the SUI model in the bladder of female rats caused the state of overactivity, as muscle membranes of urethra and vulva became moderately atonic.

\begin{tabular}{|c|c|c|c|}
\hline \multirow{2}{*}{ Blood vessels of the microcirculatory bed } & \multirow{2}{*}{$\begin{array}{c}\text { Diameter of vascular lumen in animals } \\
\text { of the control group }(\mu \mathrm{m})\end{array}$} & \multicolumn{2}{|c|}{ Diameter of vascular lumen in the vulva mucosal membrane proper plate $(\mu \mathrm{m})$} \\
\hline & & Group 1 & Group 2 \\
\hline Arterioles & $16.45 \pm 1.27$ & $21.43 \pm 1.81^{*}$ & $20.67 \pm 1.94^{*}$ \\
\hline Venus & $23.02 \pm 1.98$ & $33.14 \pm 2.05^{*}$ & $38.83 \pm 3.11^{*}$ \\
\hline Capillaries & $6.15 \pm 0.59$ & $7.27 \pm 0.64^{*}$ & $7.34 \pm 0.72^{*}$ \\
\hline Number of capillaries in $1 \mathrm{~mm}^{2}$ & $99.6 \pm 4.1$ & $87.3 \pm 6.2^{*}$ & $65.5 \pm 5.9^{*}$ \\
\hline
\end{tabular}

${ }^{*} p<0.05$ - the probability of indicators is compared with animals of the control group 
2. The combined model of SUI and vaginal prolapse used by us was successfully replicated in all animals of the experimental group, which was confirmed by revealed morphofunctional changes of the bladder, urethra and vulva tissues.

3. Functional changes dominated in animals with the SUI model. In animals with a combined model of SUI and vaginal prolapse, the functional changes predominantly manifested on Day 14, and changes in the architectonics of the study organs emerged within 30 days.

\section{REFERENCES/ЛITEPATУPA}

\section{Petros, P.}

The Female Pelvic Floor. Function, Dysfunction and Management According to the Integral Theory. New York (2007).

2. Popov, A.A.

Modern aspects of diagnostics, classification and surgical treatment of descent and prolapse of female genital organs. Thesis abstract for MD degree. Moscow (2001): 38 p. Попов, А.A.

Современные аспекты диагностики, классификации и хирургического лечения опущения и выпадения женских половых органов. Автореф. дисс. ... д. мед. н. M., 2001. -38 c.

3. Smolnova, T.Y., Adamian, L.V., Sidorov, V.V.

"Special aspects of microcirculation in descent and prolapse of the internal genital organs in women of reproductive age." Obstetrics and Gynecology 1 (2007): 39-44.

Смольнова, Т.Ю.

Особенности микроциркуляции при опущении и выпадении внутренних половых органов у женщин репродуктивного возраста / Т.Ю. Смольнова, Л.В. Адамян, В.В. Сидоров // Акушерство и гинекология. - 2007. - № 1. - С. 39-44.

4. Troiano, L., Pregazzi, R., Bortoli, P., Madai, M.

"Postpartum urogenital and perineal prolapse." Minerva Gynaec 52.7-8 (2000): 299-305.

5. Sanakoeva, T.M.

Special aspects of surgical correction of genital prolapse in elderly and senile patients. Thesis abstract for PhD degree. Moscow (2004): 24 p.

Санакоева Т.М.

Особенности хирургической коррекции опущения гениталий у пациенток пожилого и старческого возраста. Автореф. дисс. ... к. мед. н. М., 2004. - 24 с.

6. Mawajdeh, S.M., Al-Qutob, R.J., Farag, A.M.

"Prevalence and risk factors of genital prolapse. A multicenter study." Saudi Med J 24.2 (2003): 161-5.

7. Falconer, $\mathrm{C}$.

"Decreased collagen synthesis in stress-incontinent women." Obstet Gynaec 84.4

(1994): 583-6.

8. Goh, J.T.

"Biomechanical properties of prolapsed vaginal tissue in pre- and postmenopausal women." Int Urogynecol Pelvic Floor Dysfunct 13 (2002): 76-9.

9. Silva, W.A., Karram, M.M.

Vaginal surgery for incontinence and prolapse. London. Springer (2006).

10. Krasnopolskij, V.I., Bujanova, S.N.

"Descent and prolapse of vagina and uterus." In: Diseases of the cervix, vagina and vulva, ed. by V.N. Prilepskaja. Moscow. MEDpress-inform (2003); 367-96.

Краснопольский, В.И.

Опущения и выпадения влагалища и матки / В.И. Краснопольский, С.Н. Буянова // Заболевания шейки матки, влагалища и вульвы. Под ред. В.Н. Прилепской. - М.: МЕДпресс-информ, 2003. -С. 367-396.

11. Smolnova, T.Y., Bujanova, S.N., Saveljev, S.V., Petrova V.D.

"Connective tissue dysplasia as one of the causes of urinary incontinence in women with prolapse." Urology 2 (2001): 25-30.

Смольнова, Т.Ю.

Дисплазия соединительной ткани как одна из причин недержания мочи у женщин с пролапсом / Т.Ю. Смольнова, С.Н. Буянова, С.В. Савельев, В.Д. Петрова

// Урология. -2001 . - №2. - С. 25-30.
4. Replication of the combined SUI + VP model resulted in edema of vulva tissues, accompanied by the growth and consolidation of collagen fiber bundles, mucosal and muscular membrane atrophy, and a decrease of density of microcirculatory bed vessels.

5. Pathological changes of the vulva structural elements after application of the combined model suggested a trophic disturbance, which was confirmed by a decrease in the density of capillaries by $34.24 \%$ and fibrosis of arteriolar membranes.

6 . The complex model studied by us can be used for further research on the experimental treatment of genital prolapse.

12. Kulikovskij, V.F., Olejnik, N.V.

Pelvic prolapse in women. Moscow. GEOTAR-Media (2008): 256 p.

Куликовский, В.Ф., Олейник, Н.В.

Тазовый пролапс у женщин. - М.: ГЕОТАР-Медиа, 2008. - 256 с.

13. Brading, A.F.

"A myogenic basis for the overactive bladder." Urology 50.6 (1997): 57-67.

14. Savchuk, R.V., Kostev, F.I., Sejfullina, I.I., Shmatkova, N.V.

"Regulation of contractile activity of the bladder in vitro and in vivo." Men's health 2.29 (2009): 179-82.

Савчук, Р.В.

Регуляция сократительной активности мочевого пузыря in vitro и in vivo /

Р.В. Савчук, Ф.И. Костев, И.И. Сейфуллина, Н.В. Шматкова // Здоровье мужчины. 2009. - №2 (29). - С. 179- 182.

15. Drake, M.J., Fowler, C.J., Griffiths, D.

"Neural control of the lower urinary and gastrointestinal tracts: supraspinal CNS mechanisms." Neurourol Urodyn 29.1 (2010): 119-27.

16. MPK G09B 23/00. Patent for useful model No. 127669.

"Method of modeling stress urinary incontinence" u201804534; Announced on April 25, 2018; Published on August 10, 2015 bulletin №.5.

МПК ГО9Б 23/00. Патент на корисну модель №127669.

«Спосіб моделювання стресового нетримання сечі» и201804534. Заявлено

25.04.2018, опубліковано 10.08.18 бюл. №5.

17. Denisov, S.D.

"Requirements to scientific experiment with animal involvement." Health care 4 (2001): $40-2$.

Денисов, С.Д.

Требования к научному эксперименту с использованием животных / С.Д. Денисов // Здравоохранение. - 2001. - №4. - С. 40-42. 


\section{MORPHOFUNCTIONAL CHANGES OF THE PELVIC ORGANS UNDER CONDITIONS OF STRESS URINARY INCONTINENCE AND EXPERIMENTAL VAGINAL PROLAPSE}

T.F. Tatarchuk, MD, professor, corresponding member of the NAMS of Ukraine, deputy director for research work, head of the Endocrine Gynecology Department, SI "0.M. Lukyanova IPOG of the NAMS of Ukraine"

0.0. Yefimenko, PhD, senior researcher at the Endocrine Gynecology Department, SI "O.M. Lukyanova IPOG of the NAMS of Ukraine”

V.S. Shkolnikov, MD, professor, Human Anatomy Department, N.I. Pirogov Vinnitsa National Medical University

Objective of the study was to analyze the particulars of morphofunctional changes in pelvic organs under conditions of stress urinary incontinence and experimental vaginal prolapse.

Materials and methods. The experimental studies were conducted on 50 sexually mature white female rats divided into three groups. The first control group consisted of intact animals; the 2-nd group consisted of animals with replicated stress urinary incontinence model; and the 3-rd group consisted of animals with a combined model, in which, after replication of the stress urinary incontinence model, the vaginal vault fixation to sacro-uterine ligaments was broken, thus causing vaginal prolapse. After withdrawal of animals from the experiment, histological studies of bladder, urethra and vulva were carried out.

Study results. After replication of the stress urinary incontinence and vaginal prolapse model, the destructive processes in the mucous membranes of the bladder, urethra, and vulva were developing, the volume of connective tissue in muscle membranes was increasing, the collagen fibers were thickening, and one could observe changes thereof with manifestations of destruction within a 30 -day period. A combination of these processes led to an alteration of histoarchitectonics and the muscle ratio and connective tissues in membranes covering the study organs in both groups. Pathological changes accompanied by structural rebuild of bladder, urethra, and vulva tissues were more pronounced in the combined model.

Conclusions. Replication of the stress urinary incontinence model in the bladder of female rats caused an overactive state of the above, while the muscle membranes of urethra and vulva became moderately atonic. The combined stress urinary incontinence and vaginal prolapse model used by us was successfully replicated in all animals of the experimental group, which was confirmed by morphofunctional changes in the bladder, urethra and vulva tissues. Functional changes dominated in animals with the stress urinary incontinence model. The animals with a combined stress urinary incontinence and vaginal prolapse model presented with functional changes predominantly observed on day 14 , and changes in the histoarchitectonics of the study organs on day 30 . Replication of the combined stress urinary incontinence + vaginal prolapse model resulted in swelling of the vulva tissues, accompanied by growth and consolidation of collagen fiber bundles, muscular and mucosal membranes atrophy, and decreased quantity of microcirculatory bed vessels. Pathological changes in structural elements of the vulva after application of the combined model suggested a trophic disturbance, which was confirmed by a decrease in the density of capillaries by $34.24 \%$ and fibrosis of arteriolar membranes.

Keywords: experimental study, stress urinary incontinence, experimental vaginal prolapse.

\section{МОРФОФУНКЦИОНАЛЬНЫЕ ИЗМЕНЕНИЯ ОРГАНОВ МАЛОГО ТАЗА В УСЛОВИЯХ СТРЕССОВОГО НЕДЕРЖАНИЯ МОЧИ И ЭКСПЕРИМЕНТАЛЬНОГО ВЫПАДЕНИЯ ВЛАГАЛИЩА}

Т.Ф. Татарчук, д. мед. н., профессор, член-корреспондент НАМН Украины, заместитель директора по научной работе, заведующая отделением эндокринной гинекологии ГУ «ИПАГ им. акад. Е.М. Лукьяновой НАМН Украины»

0.А. Ефименко, к. мед. н., ст. науч. сотрудник отделения эндокринной гинекологии ГУ «ИПАГ им. акад. Е.М. Лукьяновой НАМН Украины»

В.С. Школьников, д. мед. Н., профессор кафедры анатомии человека Винницкого НМУ им. Н.И. Пирогова

Целью исследования стал анализ особенностей морфофункциональных изменений в органах малого таза в условиях стрессового недержания мочи и экспериментального выпадения влагалища.

Материалы и методы. Экспериментальное исследование было проведено на 50 половозрелых белых самках крыс, разделенных на три группы. Первая контрольная группа состояла из интактных животных; 2-я группа состояла из животных с реплицированной стрессовой моделью недержания мочи; 3-я группа состояла из животных с комбинированной моделью, в которой после репликации модели стрессового недержания мочи была нарушена фиксация свода влагалища крестцово-маточными связками, что привело к выпадению влагалища. После вывода животных из эксперимента были проведены гистологические исследования мочевого пузыря, мочеиспускательного канала и вульвы.

Результаты исследования. После создания стрессового недержания мочи и модели выпадения влагалища развивались деструктивные процессы в слизистых оболочках мочевого пузыря, уретры и вульвы, увеличился объем соединительной ткани в мышцах, коллагеновые волокна утолщались, и можно было наблюдать их изменения с явлениями деструкции в течение 30-дневного периода. Сочетание этих процессов привело к изменению гистоархитектоники и соотношения состава мышц и соединительной ткани в оболочках, выстилающих исследуемые органы в обеих группах. Патологические изменения, сопровождающиеся структурной перестройкой тканей мочевого пузыря, мочеиспускательного канала и вульвы, были более выраженными в комбинированной модели.

Выводы. Создание модели стрессового недержания мочи в мочевом пузыре самок крыс вызвало состояние гиперактивации, описанное выше, в то время как мышцы мочеиспускательного канала и вульвы стали умеренно атоничными. Использованная модель комбинированного стрессового недержания мочи и выпадения влагалища была успешно воспроизведена у всех животных экспериментальной группы, что было подтверждено морфофункциональными изменениями в тканях мочевого пузыря, мочеиспускательного канала и вульвы. Функциональные изменения преобладают у животных с моделью стрессового недержания мочи. У животных с комбинированной стрессовой моделью недержания мочи и выпадением влагалища возникли функциональные изменения, наблюдаемые преимущественно на 14-й день, и изменения в гистоархитектонике органов на 30-й день. Репликация комбинированной модели привела к набуханию тканей вульвы, сопровождалась ростом и уплотнением пучков коллагеновых волокон, атрофией слизистых оболочек и мышц, снижением количества сосудов микроциркуляторного русла. Патологические изменения в структурных элементах вульвы после применения комбинированной модели свидетельствуют 0 трофических нарушениях, что подтверждается снижением плотности капилляров на 34,24\% и фиброзом стенок артериол.

Ключевые слова: экспериментальное исследование, стрессовое недержание мочи, экспериментальное выпадение влагалища.

\section{МОРФОФУНКЦІОНАЛЬНІ ЗМІНИ ОРГАНІВ МАЛОГО ТАЗА В УМОВАХ СТРЕСОВОГО НЕТРИМАННЯ СЕЧІ Й ЕКСПЕРИМЕНТАЛЬНОГО ВИПАДІННЯ ПІХВИ}

Т.Ф. Татарчук, д. мед. н., професор, член-кореспондент НАМН України, заступник директора з наукової роботи, завідувачка відділенням ендокринної гінекології ДУ «ІПАГ ім. акад. О.М. Лук'янової НАМН України»

0.0. Єфіменко, к. мед. н., ст. наук. співробітник відділення ендокринної гінекології ДУ «ППАГ ім. акад. О.М. Лук'янової НАМн України»

В.С. Школьніков, д. мед. н., професор кафедри анатомії людини Вінницького НМУ ім. М.І. Пирогова

Метою дослідження був аналіз особливостей морфофункціональних змін в органах малого таза в умовах стресового нетримання сечі й експериментального випадіння піхви.

Матеріали та методи. Експериментальне дослідження було проведено на 50 статевозрілих білих самках щурів, розділених на три групи. Перша контрольна група складалася з інтактних тварин; 2-я група складалася з тварин, реплікованих на стресову модель нетримання сечі; 3-тя група складалася 3 тварин 3 комбінованою моделлю, в якій після реплікації моделі стресового нетримання сечі була порушена фіксація зводу піхви крижово-матковими зв'язками, що призвело до випадіння піхви. Після виведення тварин з експерименту були проведені гістологічні дослідження сечового міхура, сечовипускального каналу і вульви.

Результати дослідження. Після створення стресового нетримання сечі і моделі випадіння піхви розвивалися деструктивні процеси в слизових оболонках сечового міхура, уретри і вульви, збільшився об'єм сполучної тканини в м'язах, колагенові волокна товщали, і можна було спостерігати їхні зміни з явищами деструкції протягом 30-денного періоду. Поєднання цих процесів призвело до зміни гістоархітектоніки і співвідношення складу м'язів і сполучної тканини в оболонках, що вистилають досліджувані органи в обох групах. Патологічні зміни, що супроводжуються структурною перебудовою тканин сечового міхура, сечовипускального каналу і вульви, були більш вираженими в комбінованій моделі.

Висновки. Створення моделі стресового нетримання сечі в сечовому міхурі самок щурів викликало стан гіперактивації, описаний вище, тоді як м'язи сечівника і вульви стали помірно атонічними. Використана модель комбінованого стресового нетримання сечі й випадіння піхви була успішно відтворена в усіх тварин експериментальної групи, що було підтверджено морфофункціональними змінами в тканинах сечового міхура, сечовипускального каналу і вульви. Функціональні зміни переважають у тварин $з$ моделлю стресового нетримання сечі. У тварин із комбінованою стресовою моделлю нетримання сечі і випадінням піхви виникли функціональні зміни, що спостерігаються переважно на 14-й день, і зміни в гістоархітектоніці органів на 30-й день. Реплікація комбінованої моделі призвела до набухання тканин вульви, супроводжувалася зростанням й ущільненням пучків колагенових волокон, атрофією слизових оболонок і м'язів, зниженням кількості судин мікроциркуляторного русла. Патологічні зміни в структурних елементах вульви після застосування комбінованої моделі свідчать про трофічні порушення, що підтверджується зниженням щільності капілярів на 34,24\% і фіброзом стінок артеріол.

Ключові слова: експериментальне дослідження, стресове нетримання сечі, експериментальне випадіння піхви. 